\title{
Effect of Black Soldier Fly (Hermetia illucens) meals on the meat quality in broilers
}

\author{
Teodora Popova, Evgeni Petkov and Maya Ignatova \\ Institute of Animal Science-Kostinbrod, Agricultural Academy, Bulgaria \\ e-mail: tlpopova@yahoo.com
}

\begin{abstract}
The experiment aimed to assess the effect of dietary inclusion of meals derived from Black soldier fly (BSF) larvae on the meat quality in broilers. The birds were divided into three groups according to the formulated diets: control (CON)- receiving standard diet, $\mathrm{T} 1$ - receiving $5 \%$ partially defatted and $\mathrm{T} 2$ - receiving $5 \%$ full fat $\mathrm{BSF}$ meal during the finishing period (14-35 d). At the age of 35 days, 10 broilers from each group were slaughtered for meat quality evaluation. The dietary inclusion of the BSF meals was associated with decrease of $\mathrm{pH}$ and lighter colour of the meat. The total amount of the saturated fatty acids (SFA) and atherogenic index (AI) were increased, while polyunsaturated fatty acids (PUFA), the ratios between PUFA and SFA (P/S), n-6/n-3 PUFA and hypo/hypercholesterolemic fatty acids $(\mathrm{h} / \mathrm{H})$ were decreased in the meat of the broilers consuming insect meals. The results of the study suggest good prospective for further research with the examined BSF meals for broiler nutrition to formulate feeding strategies that will not alter negatively meat quality and its healthy value.
\end{abstract}

Key words: edible insects, protein, poultry, fatty acids

\section{Introduction}

In recent years, edible insects have been gaining much attention on the feed market mainly due to their high protein content that is essential for the growth of the farm animals. In the poultry industry, as well, the demand for high-quality protein is increasing, hence increasing the demand for edible insects for the poultry feed. Black soldier fly (BSF) (Hermetica illucens) and the common housefly (Musca domestica) are two insect species mainly being investigated. Recently, research has been done also on yellow mealworm (Tenebrio molitor) (Bovera et al. 2016, Biasato et al. 2017, Benzertiha et al. 2019), silkworm (ljaiya and Eko 2009, Dutta et al. 2012, Ullah et al. 2017), crickets (Wang et al. 2005) and grasshoppers (Sun et al. 2013). BSF larvae are an excellent energy and protein source. It has been stated that their amino acid profile is suitable for poultry (Barragan-Fonseca et al. 2017). According to De Marco et al. (2015) the high apparent metabolisable energy and the amino acid apparent ileal digestibility coefficients of BSF larval meal, make it a valuable ingredient for the formulation of broiler feeds. Furthermore, Arango Gutiérrez (2005) suggested that BSF larvae have a suitable mineral content for the nutrition of poultry. On the other hand, BSF larvae contain high amounts of lipids whose fatty acid profile vary considerably depending on the composition of the rearing substrate. The lipids of the BSF larvae are characterized with large amounts of saturated fatty acids (58-72\%), with significant levels of C12:0, C16:0 and C18:1 (Surendra et al. 2016). Studies on the application of BSF larvae meal in poultry feeds are carried out with broilers (Dabbou et al. 2018, Kinasih et al. 2018, Schiavone et al. 2019), ducks (Gariglio et al. 2019), quails (Cullere et al. 2016) and partridges (Loponte et al. 2017, Secci et al. 2018) evaluating the performance parameters of the birds, as well as, meat quality traits. Most of the studies focus on the application of different percentages of defatted meal derived from BSF larvae while few reported on the effect of the fat of BSF when added to the poultry feed (Schiavone et al. 2017, Cullere et al. 2019a). So far, to our knowledge there is no comparison between the full fat and partially defatted BSF meal as replacement of the soybean meal in the diet of broilers. The aim of this study was to evaluate and compare the effect of BSF meals (partially defatted and full fat) included in the diet of broilers on the quality, proximate composition and fatty acid profile of their meat. 


\section{AGRICULTURAL AND FOOD SCIENCE}

\section{Material and methods}

The experimental protocol used in this study, including the animal management, housing and slaughtering procedures was approved by the Ethical committee of the Institute of Animal Science- Kostinbrod, Bulgaria.

\section{Experimental birds and housing}

The trial was carried out in the experimental poultry farm of the Institute of Animal Science- Kostinbrod, Bulgaria with Ross 308 broilers. After hatching, the one day old chicks were sexed, marked and a total of 150 male chickens were selected for the trial to form three groups, each containing 50 birds. The broilers were reared in deep litter at a density of 10 birds $\mathrm{m}^{-2}$ with controlled microclimatic conditions. They were maintained at a brooding temperature of $32{ }^{\circ} \mathrm{C}$ for $7 \mathrm{~d}$ after which the environmental temperature was gradually reduced to $22^{\circ} \mathrm{C}$ until day 35. The lighting regime was $23 \mathrm{~h}$ light and $1 \mathrm{~h}$ dark for day 1 to day $7,18 \mathrm{~h}$ light and $6 \mathrm{~h}$ dark for day 8 to day 30 , and $23 \mathrm{~h}$ light and $1 \mathrm{~h}$ dark for day 31 to day 35. The temperature and lighting regimes were recommended for the standard breeding practices (Aviagen 2018). At hatching, the chickens were vaccinated against Newcastle disease, Marek disease and infectious bronchitis, and at 9 days of age - against infectious bursal disease.

\section{Experimental diets}

Full fat and partially defatted meals were derived from Black Soldier Fly (Hermetia illucens) larvae and were dry powder products. They were delivered by Nasekomo AD, Bulgaria.

\begin{tabular}{|c|c|c|c|}
\hline Component, \% & $\mathrm{CON}^{*}$ & $\mathrm{~T}^{* *}$ & $\mathrm{~T}^{* * *}$ \\
\hline Maize & 44.55 & 47.79 & 46.31 \\
\hline Wheat & 15.00 & 15.00 & 15.00 \\
\hline Soybean meal & 27.20 & 21.10 & 22.20 \\
\hline BSF meal (partially defatted) & 0.00 & 5.00 & 0.00 \\
\hline BSF meal (full fat) & 0.00 & 0.00 & 5.00 \\
\hline Sunflower meal & 5.00 & 5.00 & 5.00 \\
\hline Sunflower oil & 5.10 & 3.15 & 3.40 \\
\hline Limestone & 1.01 & 0.85 & 0.96 \\
\hline Monocalcium phosphate & 0.84 & 0.82 & 0.84 \\
\hline Salt & 0.22 & 0.22 & 0.22 \\
\hline Sodium bicarbonate & 0.22 & 0.21 & 0.21 \\
\hline L-Lys & 0.26 & 0.25 & 0.25 \\
\hline DL- Met & 0.26 & 0.27 & 0.27 \\
\hline L-Tre & 0.09 & 0.09 & 0.09 \\
\hline Choline chloride & 0.05 & 0.05 & 0.05 \\
\hline Vitamin mineral premix ${ }^{1}$ & 0.20 & 0.20 & 0.20 \\
\hline \multicolumn{4}{|l|}{ Analyzed chemical composition } \\
\hline Crude Protein, \% & 18.63 & 18.51 & 18.03 \\
\hline Fat, \% & 6.91 & 5.44 & 6.75 \\
\hline Ash, \% & 4.59 & 4.14 & 3.91 \\
\hline Crude Fibers, $\%$ & 3.95 & 4.15 & 4.73 \\
\hline Nitrogen free extract, \% & 57.59 & 59.19 & 57.99 \\
\hline Metabolizable energy ${ }^{2}, \mathrm{kcal} / \mathrm{kg}$ & 3171.16 & 3171.70 & 3170.04 \\
\hline \multicolumn{4}{|c|}{ 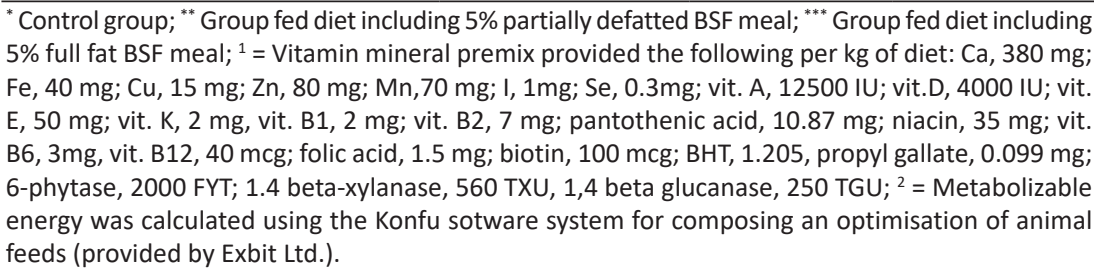 } \\
\hline
\end{tabular}




\section{AGRICULTURAL AND FOOD SCIENCE}

T. Popova et al. (2020) 29: 177-188

The feeding of the broilers was in two phases, as during the first two weeks of the trial, all the groups were fed the same starter diet adjusted to the standards for Ross broilers. For the grower period, three diets were formulated to have the same energy and crude protein levels. One of the diets was considered control (CON) while the other two were prepared to include partially defatted (T1) or full fat BSF meal (T2) at the amount of $5 \%$. The three groups of broilers $(n=50)$ were fed the respective diets for a period of three weeks until 35 days of age. Feed and fresh water were provided ad libitum. The composition of the diets was formulated according to the standard for the Ross broilers. The chemical and fatty acid composition of the diets are presented on Table 1 and Table 2 respectively, whereas the chemical composition and fatty acid profile of BSF meals can be found on Table 3. Data were provided by the Laboratory of Chemical Analyses and the Laboratory of Gas Chromatography and Lipid Analysis in the Institute of Animal Science-Kostinbrod. During the trial period, the mortality of the broilers in the three groups as well as the amount of feed provided were controlled daily, whereas the live body weight of each bird was recorded weekly.

Table 2. Fatty acid composition (\% FAME) of the diets

\begin{tabular}{lccc}
\hline Fatty acids & CON $^{*}$ & $\mathrm{T1}^{* *}$ & $\mathrm{~T}^{* * *}$ \\
\hline C12:0 & - & 9.13 & 16.63 \\
C14:0 & 0.30 & 1.58 & 2.38 \\
C16:0 & 13.69 & 15.25 & 15.93 \\
C16:1n-7 & 0.20 & 0.29 & 0.41 \\
C18:0 & 4.69 & 3.92 & 3.96 \\
C18:1 & 39.91 & 32.93 & 29.81 \\
C18:2n-6 & 40.07 & 35.56 & 29.83 \\
C18:3n-3 & 1.14 & 1.34 & 1.05 \\
\hline${ }^{*}$ Control group; ${ }^{* *}$ Group fed diet including 5\% partially defatted BSF meal; ${ }^{* * *}$ Group \\
fed diet including 5\% full fat BSF meal
\end{tabular}

\begin{tabular}{lcc}
\multicolumn{3}{l}{ Table 3. Chemical and fatty acid composition of the BSF meals } \\
Chemical composition,\% & $\begin{array}{c}\text { BSF meal } \\
\text { (partially defatted) }\end{array}$ & $\begin{array}{c}\text { BSF meal } \\
\text { (full fat) }\end{array}$ \\
\hline Crude protein & 52.17 & 43.78 \\
Fat & 17.22 & 31.14 \\
Ash & 9.38 & 6.23 \\
Crude fibers & 10.38 & 12.23 \\
Nitrogen free extracts & 6.07 & 1.83 \\
Fatty acid composition, \% & & \\
C12:0 & 41.23 & 49.56 \\
C14:0 & 8.39 & 7.90 \\
C16:0 & 18.15 & 15.17 \\
C16:1n-7 & 2.04 & 1.72 \\
C18:0 & 1.90 & 1.55 \\
C18:1 & 11.77 & 8.32 \\
C18:2n-6 & 15.61 & 14.90 \\
C18:3n-3 & 0.91 & 0.88 \\
\hline
\end{tabular}

\section{Slaughtering procedure and sampling}

At 35 days of age, a total of 30 broilers (10 birds per group) were selected for slaughter based on the average live body weight. After stunning, decapitation and bleeding, the carcasses were plucked, eviscerated and their feet removed. The edible by-products (neck, liver, gizzard, heart and spleen) were separated. Hot carcass weight (HCW) was recorded and dressing percentage was calculated. The carcasses were then kept at $4{ }^{\circ} \mathrm{C}$ for $24 \mathrm{~h}$. Further, breasts and thighs of each broiler were separated from the carcass, the skin was removed and they were subjected to analysis in the Laboratory of Meat Quality in the Institute of Animal Science- Kostinbrod. 


\title{
AGRICULTURAL AND FOOD SCIENCE
}

\section{Analysis of the meat quality traits \\ $\mathrm{pH}$ and colour measurements}

\begin{abstract}
Muscle $\mathrm{pH}$ and colour analysis was performed at the time of deboning the breast and thigh muscles from the right side of the carcass. $\mathrm{pH}$ was measured using a portable $\mathrm{pH}$ meter equipped with a glass electrode, calibrated prior to use at $\mathrm{pH} 4.0$ and 7.0. Meat colour was measured on the surface of the cranial part of each beast fillet and thigh using the CIELAB method, expressed as lightness $\left(\mathrm{L}^{*}\right)$, redness $\left(\mathrm{a}^{*}\right)$, and yellowness $\left(\mathrm{b}^{*}\right)$, with a colorimeter PCE-CSM 4 (PCE Instruments). Color saturation (chroma, $\mathrm{C}^{*}$ and the hue angle $\mathrm{h}$ ) were also measured. $\mathrm{pH}$ as well as the color measurements were done on three locations of the muscles and the results were averaged. After the analysis of $\mathrm{pH}$ and colour, the breast and thigh muscles were minced in a meat grinder. Aliquots of $300 \mathrm{mg}$ per breast and thigh meat were used for determination of WHC, and the rest was vacuum packed and stored at $-20{ }^{\circ} \mathrm{C}$ until analysis of myoglobin content, proximate composition and fatty acid profile. All the determinations in the analyses below were done in triplicate per sample.
\end{abstract}

\section{WHC determination}

Water holding capacity measured as free water content (\%) was determined as described by Grau and Hamm (1952).

\section{Myoglobin content}

Total content of myoglobin was determined (Hornsey 1956) using a T60 UV/Visible spectrophotometer (PGInstruments).

\section{Proximate composition}

The moisture, protein and ash contents of the breast and thigh meat were determined according to AOAC (2004).

Fatty acid composition of the diets and meat samples

Total lipids from the meals, feed, breast and thigh meat were extracted according to the method of Bligh and Dyer (1959). Methyl esters of the total lipids, isolated by preparative thin layer chromatography, were obtained using $0.01 \%$ solution of sulfuric acid in dry methanol for $14 \mathrm{~h}$, as described by Christie (1973). The fatty acid composition of total lipids was determined by gas-liquid chromatography (GLC) analysis using a chromatograph CSi 200 equipped with a capillary column (DM-2330:30 m×0.25 mm×0.20 $\mu \mathrm{m}$ ) and hydrogen as a carrier gas. The oven temperature was first set to $160^{\circ} \mathrm{C}$ for $0.2 \mathrm{~min}$, then raised until $220^{\circ} \mathrm{C}$ at a rate of $5^{\circ} \mathrm{C} \mathrm{min}-1$ and then held or $5 \mathrm{~min}$. The temperatures of the detector and injector were $230^{\circ} \mathrm{C}$. Methyl esters were identified through a comparison to the retention times of the standards. Fatty acids are presented as percentages of the total amount of the methyl esters (FAME) identified (Christie 1973). The amount of each fatty acid was used to calculate the atherogenic (AI) and thrombogenic (TI) indices as proposed by Ulbricht and Southgate (1991):

$A I=(C 12+4 \times C 14: 0+C 16: 0) /[M U F A+\Sigma(n-6)+\Sigma(n-3)]$

$\mathrm{TI}=(C 14: 0+C 16: 0+C 18: 0) /[0.5 \times M U F A+0.5 \times(n-6)+3 \times(n-3)+(n-3) /(n-6)]$

The h/H ratio was calculated, as suggested by Santos-Silva et al. (2002):

$h / H=(C 18: 1+C 18: 2 n-6+C 20: 4 n-6+C 18: 3 n-3+C 20: 5 n-3+C 22: 5 n-3+C 22: 6 n-3) /(C 14: 0+C 16: 0)$

\section{Statistical evaluation}

The statistical analysis was performed using JMP v.7 software package. Each bird was used as experimental unit. The normality of distribution for the data and homogeneity of variances were checked by Shapiro-Wilk and BrownForsythe tests. The effect of the BSF meals in the diet on the examined traits was evaluated through one-way ANOVA procedure. In case of significance, the means of the groups were evaluated through Tukey post hoc comparisons at $p<0.05$. 


\section{AGRICULTURAL AND FOOD SCIENCE}

\section{Results}

The health status of the birds during the trial was strictly controlled. The two groups receiving BSF meals had no mortality, while the control group had mortality of $7.55 \%$ for the whole experimental period. This could be explained with the high content of C12:0 in the diets containing BSF meals and the bactericidal effect of this fatty acid in the intestinal tract of the birds against pathogenic microorganisms. At the end of the trial period the live weight of the three groups differed significantly, as the broilers from the control group had the lowest weight (1606.30 g vs. $1692.70 \mathrm{~g}$ for T1 and $1746.82 \mathrm{~g}$ for T2). The effect of the BSF meals on the live weight was also observed on the dressing percentage, which was higher in the broilers consuming the insect meals compared to the control group (CON: 65.18\%; T1: 72.73\%; T2: 70.31\%).

\section{Quality characteristics of breast and thigh meat}

The values of $\mathrm{pH} 24$, colour and WHC of breast and thigh meat are presented in Table 4.

\begin{tabular}{|c|c|c|c|c|c|}
\hline Item & $\mathrm{CON}^{*}$ & $\mathrm{~T} 1^{* *}$ & $\mathrm{~T}^{* * *}$ & SEM & $p$ \\
\hline \multicolumn{6}{|l|}{ Breast } \\
\hline pH24 & $5.67 a$ & $5.96 a$ & $5.53 b$ & 0.18 & 0.0001 \\
\hline$L^{*}$ & $63.47 a$ & $69.52 b$ & $72.29 b$ & 4.02 & 0.0003 \\
\hline$a^{*}$ & 6.09 & 5.26 & 5.89 & 1.07 & 0.2230 \\
\hline$b^{*}$ & $7.72 \mathrm{a}$ & $6.09 b$ & $6.86 a b$ & 1.21 & 0.0253 \\
\hline $\mathrm{C}^{*}$ & $9.84 a$ & $8.09 b$ & $9.09 a b$ & 1.40 & 0.0381 \\
\hline h & 51.86 & 48.26 & 48.91 & 5.68 & 0.3623 \\
\hline WHC, \% & 36.88 & 38.04 & 39.82 & 3.25 & 0.1758 \\
\hline Myoglobin, $\mathrm{mg} \mathrm{g}^{-1}$ & $0.62 \mathrm{a}$ & $0.51 b$ & $0.53 a b$ & 0.08 & 0.0236 \\
\hline \multicolumn{6}{|l|}{ Thigh } \\
\hline $\mathrm{pH} 24$ & $6.10 a$ & $6.16 a$ & $5.70 \mathrm{~b}$ & 0.20 & 0.0001 \\
\hline$L^{*}$ & $56.94 a$ & $62.31 \mathrm{c}$ & $66.61 b$ & 3.68 & $<0.0001$ \\
\hline$a^{*}$ & 9.04 & 7.37 & 7.71 & 1.62 & 0.0854 \\
\hline$b^{*}$ & $5.64 a$ & $4.26 b$ & $5.41 a b$ & 1.12 & 0.0271 \\
\hline $\mathrm{C}^{*}$ & $10.76 a$ & $8.56 b$ & $9.44 a b$ & 1.61 & 0.0227 \\
\hline h & 32.79 & 34.89 & 30.18 & 6.41 & 0.2910 \\
\hline WHC, \% & $32.96 a$ & $34.29 a$ & $38.29 b$ & 3.23 & 0.0047 \\
\hline Myogobin, $\mathrm{mg} \mathrm{g}^{-1}$ & $1.15 a$ & $0.99 b$ & $1.02 \mathrm{ab}$ & 0.11 & 0.0181 \\
\hline
\end{tabular}

Means connected with different letters differ significantly $(p<0.05) ;{ }^{*}$ Control group; ${ }^{* *}$ Group fed diet including $5 \%$ partially defatted BSF meal; *** Group fed diet including 5\% full fat BSF meal

The inclusion of the BSF meal in the diet of broilers affected significantly $(p=0.0001) \mathrm{pH} 24$ both in breast and thigh meat, showing higher values in the control and T1 groups, when compared to T2 group. The colour characteristics were also significantly affected by the dietary BSF meal and also by its form. The groups fed BSF meals had significantly lighter colour of the breast $(p=0.0003)$ and thigh $(p<0.0001)$ when compared to control group. Furthermore, in thigh meat, differences in the lightness were observed also between T1 and T2 groups, showing the highest $L^{*}$ values in the meat of the chickens receiving full fat BSF meal. While the a* parameters remained unaffected by the BSF meals, the yellowness and colour saturation were influenced by the inclusion of the insect product and also by its form, revealing lowest values of $\mathrm{b}^{*}$ and $\mathrm{C}^{*}$ in the meat of T1 group and highest in the control. No effect of the insect meal was observed in regard to the WHC in breast, whereas in thigh decrease in the WHC in T2 was found. The effect of the BSF meal on the myoglobin content was consistent with the one observed on the yellowness and colour saturation. In both breast and thigh meat, the myoglobin content was highest in the control group and lowest inT1 group. 


\section{AGRICULTURAL AND FOOD SCIENCE}

\section{Proximate composition}

The proximate composition of the breast and thigh meat is presented in Table 5.

The content of the protein in breast was not affected by the BSF meal in the diet, while in thighs, it influenced significantly this parameter $(p=0.0048)$. In both groups receiving insect meal, the protein content was increased when compared to the control group. The muscle moisture was also affected by the BSF meals $(p<0.0001)$, however the effect differed in breast and thigh meat. While in breast lower value was displayed only in T1 group, in thigh meat, both groups receiving BSF meal had lower moisture when compared to the control group.

Table 5. Proximate composition of the breast and thigh meat

\begin{tabular}{|c|c|c|c|c|c|}
\hline Item & $\mathrm{CON}^{*}$ & $\mathrm{~T} 1^{* *}$ & $\mathrm{~T} 2^{* * *}$ & SEM & $p$ \\
\hline Protein, \% & 23.38 & 22.98 & 23.28 & 0.48 & 0.1973 \\
\hline Lipids, \% & 1.25 & 1.14 & 1.16 & 0.33 & 0.7582 \\
\hline Moisture, \% & $74.64 a$ & $72.93 b$ & $74.74 a$ & 0.64 & $<0.0001$ \\
\hline \multicolumn{6}{|l|}{ Thigh } \\
\hline Protein, \% & 19.49a & $20.07 b$ & $20.28 b$ & 0.47 & 0.0048 \\
\hline Lipids, \% & 3.95 & 4.11 & 4.55 & 0.63 & 0.1327 \\
\hline Moisture, \% & $75.45 a$ & $71.13 b$ & $73.66 \mathrm{~b}$ & 0.68 & $<0.0001$ \\
\hline
\end{tabular}

\section{Fatty acid profile}

The inclusion of the BSF meal in the diet of broilers had pronounced effect on the saturated C12:0 and C14:0 fatty acids in the breast and thigh meat $(p<0.0001)$, as shown in Table 6.

The proportion of these fatty acids gradually increased from the control group to the group that received the full fat BSF meal, showing the highest levels in the latter. C16:0 remained unaffected and C16:1n-7 only tended to increase in breast meat of the groups receiving insect meals $(p=0.0861)$. However, in thigh meat these two fatty acids were affected by the inclusion of the BSF meals in the diet and were significantly lower in the control group. In regard to the polyunsaturated fatty acids, the dietary intake of BSF meal was associated with changes in C18:2n- 6 in breast and thigh $(p<0.0001)$, decreasing considerably in T1 and T2 groups. In breast meat C22:5n-3 increased significantly $(p=0.0233)$ in the groups fed BSF meals.

The inclusion of BSF meal in the diet affected significantly the total amount of SFA in breast $(p=0.0038)$ and thigh $(p<0.0001)$ meat leading to increased valued of their percentage in T1 and T2 groups (Table 7).

MUFA were affected by the insect meals only in thigh meat $(p=0.0187)$ and displayed significantly augmented proportion in the group fed defatted BSF meal when compared to control group. T2 was intermediate in regard to this parameter. Similar to SFA, the PUFA content was significantly affected by the dietary intake of insect product in breast $(p=0.0010)$ and thigh $(p<0.0001)$ meat and showed decrease in the groups fed defatted as well as full fat BSF meal. The changes in the total SFA and PUFA reflected in the values of $\mathrm{P} / \mathrm{S}$ ratio, which were significantly lower $(p<0.0001)$ in the meat of broilers receiving BSF meals. Furthermore, both T1 and T2 groups displayed lower $n-6 / n-3$ and $h / H$ ratios, however the atherogenic index was augmented when compared to the control group. The TI values were influenced by the diet as well, but they differed significantly between the groups only in the thigh meat $(p<0.0001)$, being higher in the meat of broilers receiving BSF meals compared to the control group. 
Table 6. Fatty acid (\% FAME) composition of the breast and thigh meat

\begin{tabular}{|c|c|c|c|c|c|}
\hline Fatty acids & $\mathrm{CON}^{*}$ & $\mathrm{~T} 1^{* *}$ & $\mathrm{~T} 2^{* * *}$ & SEM & $p$ \\
\hline \multicolumn{6}{|l|}{ Breast } \\
\hline C12:0 & $0.19 a$ & $1.07 \mathrm{~b}$ & $2.52 \mathrm{c}$ & 0.64 & $<0.0001$ \\
\hline C14:0 & $0.45 a$ & $0.82 b$ & $1.30 c$ & 0.18 & $<0.0001$ \\
\hline C16:0 & 20.95 & 21.57 & 21.04 & 1.80 & 0.6994 \\
\hline C16:1n-7 & 2.67 & 3.49 & 3.14 & 0.79 & 0.0861 \\
\hline C18:0 & 6.47 & 7.24 & 6.97 & 1.23 & 0.3898 \\
\hline C18:1n-9 & 34.16 & 35.70 & 33.33 & 3.26 & 0.2765 \\
\hline$C 18: 2 n-6$ & $30.21 a$ & $24.48 \mathrm{~b}$ & $26.03 b$ & 1.98 & $<0.0001$ \\
\hline C18:3n-3 & 0.38 & 0.41 & 0.42 & 0.08 & 0.5026 \\
\hline$C 20: 2 n-6$ & 0.53 & 0.56 & 0.60 & 0.13 & 0.5579 \\
\hline$C 20: 3 n-6$ & $0.47 a$ & $0.71 b$ & $0.67 \mathrm{~b}$ & 0.12 & 0.0004 \\
\hline$C 20: 4 n-6$ & 3.20 & 3.49 & 3.45 & 0.86 & 0.3471 \\
\hline$C 20: 5 n-3$ & 0.03 & 0.07 & 0.06 & 0.03 & 0.1158 \\
\hline$C 22: 5 n-3$ & $0.16 a$ & $0.23 a b$ & $0.25 b$ & 0.06 & 0.0233 \\
\hline$C 22: 6 n-3$ & 0.13 & 0.16 & 0.22 & 0.16 & 0.4577 \\
\hline \multicolumn{6}{|l|}{ Thigh } \\
\hline C12:0 & $0.02 a$ & $1.58 \mathrm{~b}$ & $2.42 \mathrm{c}$ & 0.40 & $<0.0001$ \\
\hline C14:0 & $0.35 a$ & $0.98 b$ & $1.32 \mathrm{c}$ & 0.16 & $<0.0001$ \\
\hline C16:0 & $18.86 a$ & $20.60 \mathrm{~b}$ & 19.98ab & 1.31 & 0.0207 \\
\hline C16:1n-7 & 3.13a & $4.95 b$ & $4.37 \mathrm{~b}$ & 0.87 & 0.0003 \\
\hline C18:0 & 5.96 & 6.28 & 6.06 & 0.48 & 0.3310 \\
\hline C18:1n-9 & 37.31 & 38.33 & 36.71 & 1.69 & 0.1178 \\
\hline$C 18: 2 n-6$ & $31.77 a$ & $24.60 \mathrm{~b}$ & $26.63 b$ & 2.48 & $<0.0001$ \\
\hline$C 18: 3 n-3$ & 0.39 & 0.48 & 0.53 & 0.05 & 0.5603 \\
\hline$C 20: 2 n-6$ & 0.21 & 0.21 & 0.22 & 0.05 & 0.7260 \\
\hline$C 20: 3 n-6$ & $0.22 a$ & $0.28 b$ & $0.27 b$ & 0.03 & 0.0019 \\
\hline$C 20: 4 n-6$ & 1.60 & 1.52 & 1.33 & 0.25 & 0.0659 \\
\hline$C 20: 5 n-3$ & 0.00 & 0.01 & 0.01 & 0.01 & 0.1855 \\
\hline$C 22: 5 n-3$ & 0.11 & 0.11 & 0.09 & 0.02 & 0.3094 \\
\hline$C 22: 6 n-3$ & 0.07 & 0.07 & 0.06 & 0.02 & 0.8357 \\
\hline
\end{tabular}

Means connected with different letters differ significantly $(p<0.05)$. ${ }^{*}$ Control group $;{ }^{* *}$ Group fed diet including $5 \%$ partially defatted BSF meal; ${ }^{* *}$ Group fed diet including $5 \%$ full fat BSF meal 
Table 7. Total content of fatty acids and lipid nutritional indices in breast and thigh meat

\begin{tabular}{|c|c|c|c|c|c|}
\hline Item & $\mathrm{CON}^{*}$ & $\mathrm{~T}^{* *}$ & $\mathrm{~T} 2^{* * *}$ & SEM & $p$ \\
\hline \multicolumn{6}{|l|}{ Breast } \\
\hline SFA & $28.06 a$ & $30.70 \mathrm{~b}$ & $31.83 b$ & 2.33 & 0.0038 \\
\hline MUFA & 36.83 & 39.18 & 36.47 & 3.65 & 0.2147 \\
\hline PUFA & $35.11 a$ & $30.11 b$ & $31.70 \mathrm{~b}$ & 2.70 & 0.0010 \\
\hline$n-6$ & $34.41 a$ & $29.24 b$ & $30.75 b$ & 2.60 & 0.0005 \\
\hline$n-3$ & 0.70 & 0.87 & 0.95 & 0.22 & 0.0579 \\
\hline $\mathrm{P} / \mathrm{S}$ & $1.25 a$ & $0.98 b$ & $0.99 b$ & 0.12 & $<0.0001$ \\
\hline$n-6 / n-3$ & $49.16 a$ & $33.61 \mathrm{~b}$ & $32.36 \mathrm{~b}$ & 3.34 & 0.0012 \\
\hline Al & $0.32 \mathrm{a}$ & $0.37 b$ & $0.42 b$ & 0.04 & 0.0002 \\
\hline TI & 0.74 & 0.80 & 0.80 & 0.08 & 0.1954 \\
\hline$h / H$ & $3.26 a$ & $2.88 \mathrm{~b}$ & $2.87 \mathrm{~b}$ & 0.36 & 0.0397 \\
\hline \multicolumn{6}{|l|}{ Thigh } \\
\hline SFA & $25.19 a$ & $29.44 b$ & $29.78 b$ & 1.42 & $<0.0001$ \\
\hline MUFA & $40.44 a$ & $43.28 \mathrm{~b}$ & 41.08ab & 2.18 & 0.0187 \\
\hline PUFA & $34.37 a$ & $27.28 b$ & $29.14 b$ & 2.66 & $<0.0001$ \\
\hline$n-6$ & $33.80 a$ & $26.61 b$ & $28.45 b$ & 2.60 & $<0.0001$ \\
\hline$n-3$ & $0.57 a$ & $0.67 b$ & $0.69 b$ & 0.07 & 0.0016 \\
\hline $\mathrm{P} / \mathrm{S}$ & $1.36 a$ & $0.93 b$ & $0.98 b$ & 0.14 & $<0.0001$ \\
\hline$n-6 / n-3$ & $59.29 a$ & $39.71 b$ & $41.24 b$ & 4.11 & $<0.0001$ \\
\hline Al & $0.27 a$ & $0.37 b$ & $0.40 b$ & 0.03 & $<0.0001$ \\
\hline TI & $0.52 \mathrm{a}$ & $0.62 b$ & $0.60 \mathrm{~b}$ & 0.04 & $<0.0001$ \\
\hline$h / H$ & $3.74 a$ & $3.02 b$ & $3.09 b$ & 0.30 & $<0.0001$ \\
\hline
\end{tabular}

Means connected with different letters differ significantly $(p<0.05) .{ }^{*}$ Control group; ${ }^{* *}$ Group fed diet including $5 \%$ partially defatted BSF meal;

${ }^{* * *}$ Group fed diet including $5 \%$ full fat BSF meal

\section{Discussion}

The results of the present study show that the values of $\mathrm{pH} 24$ in the broiler meat can be diversely affected by the inclusion of the BSF meal in the diet and might depend on its form (full fat or partially defatted product). The $\mathrm{pH}$ value of the meat is an important parameter regarding the transformation of muscle tissue in meat and depends on the rate of decomposition of glycogen deposits in the muscles. The very rapid decline of $\mathrm{pH}$ early post mortem is associated with the abnormal pale colour and reduced water holding capacity (PSE) meat. In poultry meat such abnormalities exist, as broilers are most prone to them, due to the rapid growth rates and the hypertrophy of muscles, especially breast. Studies on broiler meat quality report different values for the $\mathrm{pH}$ in normal and PSElike meat in breast, and such have been not pointed for thigh muscles. The $\mathrm{pH} 24$ values of the breast in this study are within the normal range for the control and T1 groups (Fletcher 1999, Zhang and Barbut 2005, Lesiow et al. 2009), however it was significantly lowered in the group consuming full fat BSF meal. It is known that BSF larvae are rich in lauric acid and hence the products derived by them would have considerable levels of this fatty acid. It could be suggested that the augmented content of lauric acid in the full fat BSF meal is responsible for the lower values of $\mathrm{pH}$ in the broilers meat, however the results so far have been inconsistent. Zeiger et al. (2017) reported significantly lower $\mathrm{pH}$ in the breast muscles in broilers receiving lauric acid in the diet but dependent on the broiler strain. On the other hand, Schiavone et al. (2017) did not find any changes in pH in meat of broilers fed diets with partial or total replacement of the soya with BSF larvae fat. Cullere et al. (2016), reported significant decrease in the $\mathrm{pH}$ value quails breast meat when receiving defatted BSF meal in the diet, similar trends were further observed in quails with $10 \%$ dried and ground BSF larvae in the diet (Cullere et al. 2019b). Lower pH values are associated with decrease in the WHC and lighter colour. In our study WHC tended to be lower in the groups fed BSF meal and significantly deteriorated in the thigh of T2 group. Increased drip losses and deteriorated WHC due to intake of elevated lauric acid levels were reported by Zeiger et al. (2017) and Fortuoso et al. (2019), however Schiavone et al. $(2017,2019)$ did not find any changes in the drip loss due to BSF fat or meal. 


\section{AGRICULTURAL AND FOOD SCIENCE}

T. Popova et al. (2020) 29: 177-188

The lightness of the breast and thigh meat in this study increased significantly in T1 and T2 groups when compared to the chickens from the control group. The highest $L^{*}$ values were registered in the chickens fed full fat BSF meal. This corresponded to the lowest WHC associated with the lowest $\mathrm{pH}$ values and hence more moisture on the surface of the meat to reflect the light in this group. This result was not expected and requires further investigation. In regard to the $b^{*}$ and $C^{*}$ values, however, T2 group was intermediate. These two parameters were significantly affected by the inclusion of BSF meal in the diet but their lowest values were observed in T1 group. The highest $b^{*}$ and $C^{*}$ values were recorded in the control group which corresponded with the darkest colour of the breast and thigh meat as well as the highest myoglobin content. Colour is one of the meat quality parameters that affect considerably the perception of consumers. So far, the observations on the effect of the insect meals as a component of the diet in poultry on the colour characteristics of meat have been contradictory. In line with our results, Schiavone et al. (2019) observed reduced yellowness in meat of broilers receiving defatted BSF meal in the diet, however they reported increased redness in response to the BSF meal. On the other hand, Schiavone et al. (2017) did not find any significant changes in the colour of broiler breast meat either fresh or subjected to 9 days of retail display that were due to the dietary intake of BSF fat. Cullere et al. (2016) reported dose dependent effect of BSF defatted meal on the redness index of quail breast with decrease of its values in the birds consumed higher content of the meal. Secci et al. (2018) detected increased yellowness in cooked partridge meat from birds fed BSF and Tenebrio molitor meal, but no changes were observed in the fresh meat. Pieterse et al. (2019) did not find any difference in the colour characteristics of meat in broilers fed pre-pupae BSF meals included in the diet. On the other hand, in an earlier study, Pieterse et al. (2014) found decreased lightness and redness in breast and decreased yellowness in thigh meat of broilers receiving Musca domestica larvae meal, replacing fish meal in the diet. We consider that the changes in the colour parameters attributable to the dietary inclusion of BSF meal affected considerably the visual appearance of the meat with possible impact on the choice of the consumers.

The proximate composition of the meat was affected by the inclusion of the BSF meal in the diet. Both kinds of meat displayed changes in the moisture content that in breast was the lowest in T1 group, while in thigh the decrease of this parameter was observed in both groups receiving BSF meals. The decreased moisture in thigh however corresponded with the tendency toward higher lipid deposition, while on the other hand the protein content in the broilers consuming insect meals was also higher. Similar to the physical traits, no consistent effect of the insect products on the proximate composition of the meat has been reported. Our results are in partial agreement with Schiavone et al. (2019), reporting higher protein content and decreased moisture content in response to increasing level of BSF defatted meal in broilers. The proximate composition of broiler meat remained unaffected by the inclusion of BSF larvae (Cullere et al. 2019b) or other insect sources such as Tenebrio molitor (Bovera et al. 2016, Dabbou et al. 2019).

The fatty acid profile is of great importance for the healthy value of food. One of the factors that greatly affect the fatty acid composition of meat is the nutrition of the animals it is derived from. In this study, the fatty acid profile of breast and thigh meat revealed dramatic increase in the content of C12:0. This is expected since the BSF meals contain significant amount of lauric acid (Table 3). The increase of the proportion of C12:0 was accompanied by higher content of C14:0 and total SFA in breast and thigh meat. C16:0 was only augmented in the thigh meat, more pounced in T1 group. Our results coincide with those reported by Schiavone at al. (2017), Cullere et al. (2019a), Schiavone et al. (2019), who observed linear increase in the content of lauric and myristic acids in the meat of broilers with partial or total replacement of the soya oil with fat derived from BSF larvae or increasing amounts of defatted BSF meal respectively.

The monounsaturated fatty acid that was affected by the dietary inclusion of the insect meals was C16:1n-7 which increased in the groups fed both full and partially defatted BSF meals. Its increase was more pronounced in thigh meat and led to higher total amount of MUFA observed in this meat. Though it tended to be increased in the breast, its amounts were not sufficient to induce increase in the total MUFA. In line with our results, Cullere et al. (2019a) and Sciavone et al. (2019) observed increase in C16:1 in the breast and thigh meat of broilers receiving dietary BSF fat, however they reported contradictory results in regard to C18:1. The lack of changes in C18:1n-9 that we observed might be attributed to the higher intake of dietary SFA in the groups fed BSF meals. According to Poureslami et al. (2010), dietary surplus of SFA inhibits the biosynthesis of C18:1n-9 by suppressing the elongase activity. Furthermore, according to Kouba and Mourot (1998) and Smink et al. (2010), the high dietary PUFA intake expected in this study due to the high amounts of C18:2n-6 in the diets (Table 2), might inhibit the $\delta-9$ desaturase in the liver and reduce the conversion of SFA to MUFA.

The results of the study show significant decrease in the C18:2n- 6 in the groups consumed BSF meals. It is known that C18:2 n-6 is essential for the organism and is exclusively derived from the diet. Since both BSF meals in the 


\section{AGRICULTURAL AND FOOD SCIENCE}

T. Popova et al. (2020) 29: 177-188

diet of the broilers are included to replace the soybean meal, which is rich in C18:2 n-6, the decrease in the content of this fatty acid in the meat could be expected and due to its lower intake from the diet. Contrary to us, Cullere et al. (2018) did not observe any effect of BSF in the diet on the C18:2n-6, while Schiavone et al. (2017) reported increase of C18:2n-6 in the meat of broilers with increased levels of BSF in the diet. The n-3 PUFA content tended to increase in breast $(p=0.0579)$ in breast of T1 and T2 groups which contradicts to the findings of Secci et al. (2018) and Schiavone et al. (2019), reporting significant decrease in the long chain n-3 PUFA. The decrease in C18:2n-6 lead to lower n-6/n-3 ratio, however it remained very high in all the groups. The recommended values of this ratio are $<4$ (Enser et al. 2001), whereas the reported in this study are far beyond this value, which indicates necessary further modifications of the diet of the birds, so that they meet the criteria for a healthy and balanced fatty acid profile. On the other hand, the P/S ratio are above the recommended minimum of 0.4 (Wood et al. 2003). The significant increase of SFA and particularly C14:0 is associated with increase in Al, $\mathrm{TI}$ and decrease in $\mathrm{h} / \mathrm{H}$. Atherogenic and thrombogenic indices are lipid quality indicators that depend on the changes of particular groups of fatty acids. They indicate the potential effects of the lipids on the development of cardiovascular diseases. Both Al and TI showed increase in the breast and thigh meat of broilers consuming BSF meals, the maximum values observed in T2 group. This corresponds to the significantly higher content of SFA in the groups fed BSF meals. Attia et al. (2017) observed significant positive relationship between SFA and Al and TI in broiler meat. Schiavone et al. (2019) observed linear increase in Al of the breast meat in broilers, receiving diets including 50$150 \mathrm{~g} \mathrm{~kg}^{-1}$ partially defatted BSF meal. They reported values within the range of $0.29-0.34$. On the other hand, they did not observe any effect of the BSF meal on the thrombogenic index (0.61-0.64) which coincides with our results for the breast meat. Cullere et al. (2019a) reported significant increase of the Al and TI in broilers consuming diets with $50 \%$ and $00 \%$ replacement of the soybean oil with oil derived from BSF larvae. The Al and TI values determined in this study might be considered low when compared to other studies with boilers (Attia et al. 2017, del Puerto et al. 2017, Cullere et al. 2019a) which indicates no negative effect of the BSF meals on the lipid quality.

\section{Conclusions}

The present study shows that the inclusion of $5 \%$ of full fat or partially defatted meal derived from the Black Soldier fly larvae in the diet affected considerably the quality characteristics and fatty acids profile of meat in broilers at 35 days of age. Mostly, changes were associated with decrease of pH 24 and the lighter colour in the groups consuming BSF meals. Furthermore, significant increase in SFA, mainly due to higher content of C12:0 and $\mathrm{C} 14: 0$ and decrease in PUFAin the meat of the chickens that received BSF meals was observed. These changes led to higher atherogenic and thrombogenic indices of the meat of the broilers in the experimental groups. The results suggest that further research is necessary in order to formulate feeding strategies in broiler nutrition with participation of the examined BSF products that will not alter adversely the meat quality.

\section{Aknowledgements}

The authors would like to acknowledge the kind support of Nasekomo AD.

\section{References}

AOAC 2004. Official methods of analysis, 18th Ed. Association of Official Analytical Chemists, Arlington, VA, USA.

Arango Gutiérrez, G.P. 2005. Aportes nutricionales de la biomasa de Hermetia illucens L. (Diptera: Stratiomyidae) en la cría de pollos de engorde. MSc thesis, Universidad Nacional de Colombia, Bogotá, Colombia.

Attia, Y.A., Al-Harthi, M.A., Korish, M.A. \& Shiboob, M.M. 2017. Fatty acid and cholesterol profiles, hypocholesterolemic, atherogenic, and thrombogenic indices of broiler meat in the retail market. Lipids in Health and Disease 16:40. https://doi.org/10.1186/s12944-017-0423-8

Aviagen 2018. Ross Broilers Management Handbook. 147 p. http://eu.aviagen.com/assets/Tech_Center/Ross_Broiler/Ross-BroilerHandbook2018-EN.pdf

Barragan-Fonseca, K.B., Dicke, M. \& van Loon, J.J.A. 2017. Nutritional value of the black soldier fly (Hermetia illucens L.) and its suitability as animal feed - a review. Journal of Insects as Food and Feed 3: 105-120. https://doi.org/10.3920/JIFF2016.0055

Benzertiha, A., Kierończyk, B., Kołodziejski, P., Pruszyńska-Oszmałek, E., Rawski, M., Józefiak, D. \& Józefiak, A. 2019. Tenebrio molitor and Zophobas morio full-fat meals as functional feed additives affect broiler chickens' growth performance and immune system traits. Poultry Science: pez450. https://doi.org/10.3382/ps/pez450

Biasato, I., Gasco, L., De Marco, M., Renna, M., Rotolo, L., Dabbou, S., Capucchio, M.T., Biasibetti, E., Tarantola, M., Sterpone, L., Cavallarin, L., Gai, F., Pozzo, L., Bergagna, S., Dezzutto, D., Zoccarato, I. \& Schiavone, A. 2017. Yellow mealworm larvae (Tenebrio molitor) inclusion in diets for male broiler chickens: effects on growth performance, gut morphology, and histological findings. Poultry Science 97: 540-548. https://doi.org/10.3382/ps/pex308 
Bligh, E.G. \& Dyer, W.Y. 1959. A rapid method of total lipid extraction and purification. Canadian Journal of Biochemistry and Physiology 37: 911-917. https://doi.org/10.1139/059-099

Bovera, F., Loponte, R., Marono, S., Piccolo, G., Parisi, G., Iaconisi, V., Gasco, L. \& Nizza, A. 2016. Use of Tenebrio molitor larvae meal as protein sourcein broiler diet: effect on growth performance, nutrient digestibility, and carcass and meat traits. Journal of Animal Science 94: 639-647. https://doi.org/10.2527/jas.2015-9201

Christie, W.W. 1973. Lipid analysis. Pergamon Press. Oxford. 352 p.

Cullere, M., Schiavone, A., Dabbou, S., Gasco, L. \& Dalle Zotte, A. 2019a. Meat quality and sensory traits of finisher broiler chickens fed with Black Soldier Fly (Hermetia Illucens L.) larvae fat as alternative fat source. Animals (Basel) 9: 140. https://doi.org/10.3390/ani9040140

Cullere, M., Woods, M.J., van Emmenes, L., Pieterse, E., Hoffman, L.C. \& Dalle Zotte, A. 2019b. Hermetia illucens larvae reared on different substrates in broiler quail diets: effect on physicochemical and sensory quality of the quail meat. Animals (Basel) 9 : 525. https://doi.org/10.3390/ani9080525

Cullere, M., Tasoniero, G., Giaccone, V., Acuti, G., Marangon, A. \& Dalle Zotte, A. 2018. Black soldier fly as dietary protein source for broiler quails: meat proximate composition, fatty acid and amino acid profile, oxidative status and sensory traits. Animal 12 : 640-647. https://doi.org/10.1017/S1751731117001860

Cullere, M., Tasoniero, G., Giaccone, V., Miotti-Scapin, R., Claeys, E., De Smet, S. \& Dalle Zotte, A. 2016. Black soldier fly as dietary protein source for broiler quails: apparent digestibility, excreta microbial load, feed choice, performance, carcassand meat traits. Animal 10: 1923-1930. https://doi.org/10.1017/S1751731116001270

Dabbou, S., Gai, F., Biasato, I., Capucchio, M.T., Biasibetti, E., Dezzutto, D., Meneguz, M., Plachá, I., Gasco, L. \& Schiavone, A. 2018. Black soldier fly defatted meal as a dietary protein source for broiler chickens: Effects on growth performance, blood traits, gut morphology and histological features. Journal of Animal Science and Biotechnology 9:49. https://doi.org/10.1186/s40104-018-0266-9

Dabbou, S., Gasco, L., Lussiana, C., Brugiapaglia, A., Biasato, I., Renna, M., Cavallarin, L., Gai, F. \& Schiavone, A. 2019. Yellow mealworm (Tenebrio molitor L.) larvae inclusion in diets for free-range chickens: effects on meat quality and fatty acid profile. Renewable Agriculture and Food Systems 1-8. https://doi.org/10.1017/S1742170519000206

De Marco, M., Martínez, S., Hernandez, F., Madrid, J., Gai, F., Rotolo, L., Belforti, M., Bergero, D., Katz, H. \& Dabbou, S. 2015. Nutritional value of two insect larval meals (Tenebrio molitor and Hermetia illucens) for broiler chickens: apparent nutrient digestibility, apparent ileal amino acid digestibility and apparent metabolizable energy. Animal Feed Science and Technology 209: 211218. https://doi.org/10.1016/j.anifeedsci.2015.08.006

Del Puerto, M., Cabrera, C.M. \& Saadoun, A. 2017. A note on fatty acids profile of meat from broiler chickens supplemented with inorganic or organic selenium. International Journal of Food Science, Article ID 7613069. https://doi.org/10.1155/2017/7613069

Dutta, A., Dutta, S. \& Kumari, S. 2012. Growth of poultry chicks fed on formulated feed containing silk worm pupae meal as protein supplement and commercial diet. Online Journal of Animal and Feed Research 2: 303-307.

Enser, M., Scollan, N., Gulati, S., Richardson, I., Nute, G. \& Wood, J. 2001. The effects of ruminally-protected dietary lipid on the lipid composition and quality of beef muscle. In: Future of meat: Congress Proceedings of the 47th International Congress of Meat Science and Technology. Meat and Fat Research Institute, Kraków, Poland. p. 186-187.

Fletcher, D.L. 1999. Broiler breast meat color variation, pH and texture. Poultry Science 78: 1323-1327. https://doi.org/10.1093/ps/78.9.1323

Fortuoso, B.F., Dos Reis, J.H., Gebert, R.R., Barreta, M., Griss, L.G., Casagrande, R.A., de Cristo, T.G., Santiani, F., Campigotto, G., Rampazzo, L., Stefani, L.M., Boiago, M.M., Lopes, L.Q., Santos, R.C.V., Baldissera, M.D., Zanette, R.A., Tomasi, T. \& Da Silva, A.S. 2019. Glycerol monolaurate in the diet of broiler chickens replacing conventional antimicrobials: Impact on health, performance and meat quality. Microbial Pathogenesis 129: 161-167.https://doi.org/10.1016/j.micpath.2019.02.005

Gariglio, M., Dabbou, S., Biasato, I., Capucchio, M.T., Colombino, E., Hernández, F., Madrid, J., Martinez, S., Gai, F., Caimi, C., Oddon, S.B., Meneguz, M., Trocino, A., Vincenzi, R., Gasco, L. \& Schiavone, A. 2019. Nutritional effects of the dietary inclusion of partially defatted Hermetia illucens larva meal in Muscovy duck. Journal of Animal Science and Biotechnology $10: 37$. https://doi.org/10.1186/s40104-019-0344-7

Grau, R. \& Hamm, R. 1952. Eine einfache Methode zur Bestimmung der Wasserbindung im Fleisch. Die Fleischwirtschaft 4: $295-297$.

Hornsey, H.C. 1956. Color of cooked cured pork. I. Estimation of the nitric oxide-haem pigments. Journal of the Science of Food and Agriculture 23: 534-540. https://doi.org/10.1002/jsfa.2740070804

Ijaiya, A.T. \& Eko, E.O. 2009. Effect of replacing dietary fish meal with silkworm (Anaphe infracta) caterpillar meal on performance, carcass characteristics and haematological parameters of finishing broiler chicken. Pakistan Journal of Nutrition 8: 850-855. https://doi.org/10.3923/pjn.2009.850.855

JMP, Version 7. SAS Institute Inc. 2007, Cary, NC. 1989-2019.

Kinasih, I., Julita, U., Suryani, Y., Cahyanto, T., Annisa, D.S., Yuliawati, A. \& Putra, R.E. 2018. Addition of Black Soldier Fly larvae (Hermetia illucens L.) and propolis to broiler chicken performance. IOP Conference Series: Earth and Environmental Science 187: 012026. https://doi.org/10.1088/1755-1315/187/1/012026

Kouba, M. \& Mourot, J. 1998. Effect of a high linoleic acid diet on delta 9-desaturase activity, lipogenesis and lipid composition of pig subcutaneous adipose tissue. Reproduction, Nutrition, Development 38: 31-37. https://doi.org/10.1051/rnd:19980103

Lesiow, T., Sazmanko, T., Korzeniowska, M., Bobak, L. \& Oziemblowski, M. 2009. Influence of the season of the year on some technological parameters and ultrastructure of PSE, normal and DFD chicken breast muscles. In: Proceedings XIX. European Symposium on the Quality of Poultry Meat, June 2009, Turku, Finland. p. 21-25.

Loponte, R., Nizza, S., Bovera, F., De Riu, N., Fliegerova, K., Lombardi, P., Vassalotti, G., Mastellone, V., Nizza, A. \& Moniello, G. 2017. Growth performance, blood profiles and carcass traits of Barbary partridge (Alectoris barbara) fed two different insect larvae meals (Tenebrio molitor and Hermetia illucens). Research in Veterinary Science 115: 183-188.

https://doi.org/10.1016/j.rvsc.2017.04.017 


\section{AGRICULTURAL AND FOOD SCIENCE}

T. Popova et al. (2020) 29: 177-188

Pieterse, E., Erasmus, S.W., Uushona, T. \& Hoffman, L.C. 2019. Black soldier fly (Hermetia illucens) pre-pupae meal as a dietary protein source for broiler production ensures a tasty chicken with standard meat quality for every pot. Journal of the Science of Food and Agriculture 99: 893-903. https://doi.org/10.1002/jsfa.9261

Pieterse, E., Pretorius, Q., Hoffmann, L.C. \& Drew, D.W. 2014. The carcass quality, meat quality and sensory characteristics of broilers raised on diets containing either Musca domestica larvae meal, fish meal or soya bean meal as the main protein source. Animal Production Science 54: 622-628. https://doi.org/10.1071/AN13073

Poureslami, R., Turchini, G.M., Raes, K., Huyghebaert, G. \& De Smet, S. 2010. Effect of diet, sex and age on fatty acid metabolism in broiler chickens: SFA and MUFA. British Journal of Nutrition 104: 204-213. https://doi.org/10.1017/S0007114510000541

Santos-Silva, J., Bessa, R.J.B. \& Santos-Silva, F. 2002. Effect of genotype, feeding system and slaughter weight on the quality of light lambs - II. Fatty acid composition of meat. Livestock Production Science 77:187-192. https://doi.org/10.1016/S0301-6226(02)00059-3

Schiavone, A., Cullere, M., De Marco, M., Meneguz, M., Biasato, I., Bergagna, S., Dezzutto, D., Gai, F., Dabbou, S., Gasco, L. \& Dalle Zotte, A. 2017. Partial or total replacement of soybean oil by black soldier fly larvae (Hermetia illucens L.) fat in broiler diets: effect on growth performances, feed-choice, blood traits, carcass characteristics and meat quality. Italian Journal of Animal Science 16: 93-100. https://doi.org/10.1080/1828051X.2016.1249968

Schiavone, A., Dabbou, S., Petracci, M., Zampiga, M., Sirri, F., Biasato, I., Gai, F. \& Gasco, L. 2019. Black soldier fly defatted meal as a dietary protein source for broiler chickens: effects on carcass traits, breast meat quality and safety. Animal 13: $2397-2405$. https://doi.org/10.1017/S1751731119000685

Secci, G., Moniello, G., Gasco, L., Bovera, F. \& Parisi, G. 2018. Barbary partridge meat quality as affected by Hermetia illucens and Tenebrio molitor larva meals in feeds. Food Research International 112: 291-298. https://doi.org/10.1016/j.foodres.2018.06.045

Smink, W., Gerrits, W.J.J., Hovenier, R., Geelen, M.J.H., Verstegen, M.W.A. \& Beynen, A.C. 2010. Effect of dietary fat sources on fatty acid deposition and lipid metabolism in broiler chickens. Poultry Science 89: 2432-2440. https://doi.org/10.3382/ps.2010-00665

Sun, T., Long, R.J. \& Liu, Z.Y. 2013. The effect of a diet containing grasshoppers and access to free-range on carcase and meat physicochemical and sensory characteristics in broilers. British Poultry Science 54: 130-137. https://doi.org/10.1080/00071668.2012.756575

Surendra, K., Olivier, R., Tomberlin, J.K., Jha, R. \& Khanal, S.K. 2016. Bioconversion of organic wastes into biodiesel and animal feed via insect farming. Renewable Energy 98: 197-202. https://doi.org/10.1016/j.renene.2016.03.022

Ulbricht, T.L. \& Southgate, D.A.T. 1991. Coronary heart disease: seven dietary factors. Lancet 338: $985-992$. https://doi.org/10.1016/0140-6736(91)91846-M

Ullah, R., Khan, S., Hafeez, A., Sultan, A., Khan, N.A., Chand, N. \& Ahmad, N. 2017. Silkworm (Bombyx mori) meal as alt ernate protein ingredient in broiler finisher ration. Pakistan Journal of Zoology 49: 1463-1470. https://doi.org/10.17582/journal.pjz/2017.49.4.1463.1470

Wang, D.D., Zhai, S.W., Xi Zhang, C.X., Bai, Y.Y., An, S.H, \& Xu, Y.N. 2005. Evaluation on nutritional value of field crickets as a poultry feedstuff. Asian-Australasian Journal of Animal Sciences 18: 667-670. https://doi.org/10.5713/ajas.2005.667

Wood, J.D., Richardson, R.I., Nute, G.R., Fisher, A.V., Campo, M.M., Kasapidou, E., Sheard, P.R. \& Enser, M. 2003. Effects of fatty acids on meat quality: a review. Meat Science 66: 21-32. https://doi.org/10.1016/S0309-1740(03)00022-6

Zeiger, K., Popp, J., Becker, A., Hankel, J., Visscher, C., Klein, G. \& Meemken, D. 2017. Lauric acid as feed additive- An approach to reducing Campylobacter spp. in broiler meat. PLoSONE 12(4): e0175693. https://doi.org/10.1371/journal.pone.0175693

Zhang, L. \& Barbut, S. 2005. Rheological characteristics of fresh and frozen PSE, normal and DFD chicken breast meat. Poultry Science 46: 687-693. https://doi.org/10.1080/00071660500391516 